\title{
PERILAKU EKONOMI RUMAH TANGGA NELAYAN SKALA KECIL DALAM MENCAPAI KETAHANAN PANGAN DI PEDESAAN PANTAI JAWA TIMUR
}

\author{
Pudji Purwanti ${ }^{1}$ \\ 1Jurusan Sosial Ekonomi Fakultas Perikanan dan IImu Kelautan Universitas Brawijaya \\ Jl. Veteran Malang 65145 telp: 0341-553512
}

\begin{abstract}
ABSTRAK
Suatu rumah tangga dapat mencapai kondisi tahan pangan sangat berkaitan erat dengan perilaku ekonomi rumah tangga, dalam hal ini pengambilan keputusan rumah tangga dalam kegiatan produksi dan konsumsi, serta alokasi waktu kerja dan pendapatan rumah tangga. Penelitian ini menggambarkan perilaku rumah tangga nelayan skala kecil dalam mencapai ketahanan pangan di Kabupaten Pasuruan dan Kabupaten Trenggalek. Data primer dan sekunder digunakan dalam penelitian ini. Data primer diperoleh melalui survei lapang; sedangkan data sekunder diperoleh melalui studi dan kompilasi data statistik terkait topik studi. Data dianalisis secara ekonometrik melalui pendekatan ekonomi rumah tangga. Hasil penelitian menunjukkan bahwa dalam mencapai ketahanan pangan, rumahtangga nelayan melakukan kegiatan produksi melaut dan non perikanan sebagai sumber pendapatan dari sektor perikanan dan non perikanan. Kredit non formal lebih digunakan untuk konsumsi pangan. Pada pola konsumsi pangan seimbang, ikan menduduki peringkat kedua setelah konsumsi beras. Berdasarkan parameter Indeks Porsi Pengeluaran Pangan, Indeks AKE dan Indeks AKP, maka rumahtangga nelayan skala kecil di pedesaan pantai Jawa Timur dalam kondisi tahan pangan.
\end{abstract}

Kata Kunci: Perilaku Ekonomi, RumahTangga Nelayan Skala Kecil, Ketahanan Pangan

\section{Abstract: Economic Behavior and Food Security of Small-Scaled Fisher's Household in Rural Region of East Coast of Java. By Pudji Purwanti.}

A chieving food security for household will depend on the economic behavior of such the household in terms of decision making-process of the household in production and a consumption activities and work time allocation. This research illustrated behavior of small-scale fisher's household in achieving food security in Pasuruan and Trenggalek districs. Primary and secondary data were used in this study. Primary data were collected by using survey method; secondary data were collected through literature study and compilation of statistical data related to the study theme. Data were analyzed econometrically through household economic approach. Results show that in achieving food security, fisher's household do fishing and non fisheries activity. Non formal credit scheme was mostly used for food consumption. In the food consumption ballance, fish was the second level after rice. Based on Food Expending Portion Index parameter, AKE and AKP indexes, small-scale fisher's household in rural region of East Coast of Java were in the secure food condition.

Keywords: Economic Behavior, Small-scaled Fisher Household, Food Security 


\section{PENDAHULUAN}

Ketahanan pangan merupakan konsep yang kompleks yang terkait dengan mata rantai sistem pangan dan gizi mulai dari produksi, distribusi, konsumsi dan status gizi. Ketahanan pangan menunjukkan eksistensinya, jika setiap rumah tangga selalu dapat mengakses, secara fisik maupun ekonomi, memperoleh pangan yang cukup aman dan sehat bagi seluruh anggotanya (FAO, 2005). Artinya, titik berat kondisi ketahanan pangan terletak pada tingkat rumah tangga. Ketahanan pangan ini harus mencakup aksesibilitas, ketersediaan, keamanan dan kesinambungan. Aksesibilitas di sini artinya setiap rumah tangga mampu memenuhi kecukupan pangan keluarga dengan gizi yang sehat. Ketersediaan pangan adalah rata-rata pangan dalam jumlah yang memenuhi kebutuhan konsumsi di tingkat wilayah dan rumah tangga. Sedangkan keamanan pangan dititikberatkan pada kualitas pangan yang memenuhi kebutuhan. Oleh karena itu terdapat hubungan-hubungan yang saling terkait antara kemiskinan, ketahanan pangan dan status gizi (kesehatan) dalam rumah tangga.

Dalam sistem ketahanan pangan, bukan hanya bagaimana rumah tangga mencukupi pangan yang perlu diperhatikan tetapi yang lebih penting adalah melihat kemampuan rumah tangga mengendalikan pasokan pangan untuk keluarganya (food entitlement). Salah satu upaya rumah tangga nelayan dalam rangka mencukupi kebutuhan pangan dan hidupnya adalah keputusan dalam mengalokasikan waktu kerjanya untuk berproduksi baik kegiatan pada sektor perikanan maupun pekerjaan di luar sektor perikanan. Menurut Direktorat Jenderal Perikanan (1993) sumber pendapatan nelayan dari kegiatan non perikanan seperti buruh tani, karyawan dan tukang berkisar antara 22,00 \% - 43,00 \%. Namun beberapa temuan dari hasil penelitian menunjukkan sumber pendapatan rumah tangga nelayan hanya dari sektor perikanan (Zulkifli, 1992; Muhammad dkk, 1991; Qoid, 2004). Dari sisi curahan waktu nelayan, hampir seluruh waktu kerja nelayan dihabiskan untuk kegiatan melaut (Purwanti 1994; Purwono, 1991). Beberapa peneliti telah mempelajari perilaku rumah tangga nelayan melalui pendekatan ekonomi rumah tangga nelayan dengan membagi kegiatan ekonomi rumahtangga menjadi 4 blok kegiatan ekonomi antara lain produksi, curahan kerja, pendapatan rumah tangga dan konsumsi antara lain Reniati (1998), Aryani (1994) Muhammad (2002); Sutoyo (2005) dan Tumulyadi (2005).

Tujuan penelitian adalah (1) Mempelajari perilaku rumah tangga dalam mencapai ketahanan pangan melalui pendekatan ekonomi (2) Menghitung tingkat ketahanan pangan rumah tangga nelayan

\section{METODOLOGI}

\section{Metodologi Penelitian}

Penelitian ini dilakukan di wilayah Jawa Timur. Pemilihan lokasi berdasarkan tipe sumberdaya Laut Utara dan Laut Selatan, adanya sarana pelabuhan perikanan yang menunjukkan aktivitas perekonomian masyarakat pantai serta memperoleh program pemberdayaan Departemen Kelautan dan Perikanan Propinsi Jawa Timur. Berdasarkan pertimbangan faktor diatas, maka lokasi penelitian yang mewakili wilayah Laut Selatan terpilih Desa Tasikmadu Kecamatan Watulimo Kabupaten Trenggalek. Sedangkan lokasi penelitian yang mewakili wilayah Laut Utara terpilih Desa Jatirejo Kecamatan Lekok Kabupaten Pasuruan.

Penelitian dilakukan dengan metode survei yaitu menggambarkan secara sistematik dan faktual mengenai fenomena yang ada sekarang (Nazir, 2003). Jumlah sampel dari masing-masing desa terpilih di kabupaten terpilih diambil sejumlah 40 unit usaha penangkapan ikan skala kecil secara acak sederhana (random sampling). Total contoh untuk 2 wilayah kabupaten terpilih 
adalah 80 (delapanpuluh) rumahtangga nelayan skala kecil, yang memiliki faktor produksi dengan jenis alat tangkap yang berbeda. Pengambilan sampel sejumlah 80 responden atas asumsi bahwa populasi berdistribusi normal, batasan minimum sampel sebanyak 30 unit (Walpole, 1995).

Berdasarkan data yang terkumpul dilakukan analisis deskriptif kualitatif dan kuantitatif perilaku rumah tangga nelayan melalui pendekatan ekonomi rumah tangga nelayan dengan membagi kegiatan ekonomi rumah tangga menjadi 4 blok kegiatan ekonomi antara lain produksi, curahan kerja, pendapatan rumah tangga dan konsumsi. Masing-masing blok dianalisis menggunakan metode analisis regresi berganda antara lain:

\section{Produksi melaut (Fishing production):}

QMP $=a_{0}+a_{1}$ UPJCB $+a_{2}$ JBBMP $+a_{3}$ THOKP + $a_{4} S R T+a_{5} D 1+\mu_{1}$

QMS $=b_{0}+b_{1} J B B M S+b_{2}$ THOKS $+b_{3} S R T+b_{4}$ $\mathrm{D} 2+\mathrm{b}_{5} \mathrm{D} 1+\mu_{2}$

QMP = Produksi penangkapan musim puncak (kg)/Fishing production behavior in peak season.

QMS = Produksi penangkapan musim sedang (kg)/Fishing production behavior in medium season.

UPJCB = Ukuran perahu dan jumlah cold box / Boat size variable and the numbers of cool box.

JBBMP = Jumlah bahan bakar musim puncak (It) /The number of motor fuel in peak season.

JBBMS = Jumlah bahan bakar musim sedang (It)/The number of motor fuel in medium season.

THOKP $=$ Curahan tenaga kerja musim puncak (HOK)/Fishing allocation time in peak season.

THOKS = Curahan tenaga kerja musim sedang (HOK)/Fishing allocation time in medium season.

SRT = Surplus Rumah Tangga $(R p) /$ Household surplus(Rp.).
D1 = Status sumberdaya di wilayah penangkapan ikan/Catching resource status.

D2 = Status nelayan penerima kredit atau tidak/Fisherman status whether credit receiver or not.

Curahan kerja melaut (Fishing time allocation):

THOKP $=\mathrm{C}_{0}+\mathrm{c}_{1} \mathrm{KFMP}+\mathrm{C}_{2} \mathrm{D} 1+\mu_{3}$

THOKS $=d_{0}+d_{1}$ ASET $+d_{2}$ IRT $+d_{3}$ D1 $+\mu_{4}$

THOKP = Curahan tenaga kerja melaut musim puncak (HOK)/Fishing allocation time in peak season.

THOKS = Curahan tenaga kerja melaut musim sedang (HOK) /Fishing allocation time in medium season.

KFMP = Keuntungan fishing musim puncak (Rp.)/Fishing income in peak season.

ASET = Nilai Asset kapal dan alat tangkap (Rp)/Number of asset used by fishing activities.

IRT = Total pendapatan rumahtangga nelayan (Rp/thn)/Household fisheries' total income.

\section{Biaya operasi melaut (Fishing operational cost):}

TBOMP $=e_{0}+e_{1}$ THOKP $+e_{2}$ ASET $+\mu_{5}$

TBOMS $=f_{0}+f_{1}$ THOKS $+f_{2}$ ASET $+\mu_{6}$

TBOMP = Biaya operasi melaut musim puncak (Rp.)/Fishing operational cost in peak season.

TBOMS = Biaya operasi melaut musim sedang (Rp)/Fishing operational cost in medium season.

\section{Pendapatan rumah tangga non perikanan (Non-fishing income):}

$$
\begin{aligned}
\mathrm{RNF}= & \mathrm{g}_{0}+\mathrm{g}_{1} \mathrm{KNFI}+\mathrm{g}_{2} \mathrm{KNFS}+\mathrm{g}_{3} \mathrm{PDDI}+ \\
& \mathrm{g}_{4} \mathrm{THOK}+\mu_{7} \\
\mathrm{KNFI}= & \text { Curahan kerja istri (HOK)/Wives' } \\
& \text { productivity time allocation. }
\end{aligned}
$$


KNFS = Curahan kerja non fishing suami (HOK)/Husbands' non-fishing time allocation)

PDDI = Tingkat pendidikan istri (thn)/Wives educational level.

THOK = Total hari kerja suami pada kegiatan melaut (HOK)./Total fishing time allocated days.

Pengeluaran pokok pangan (PPGN) (The major food consumption):

$$
\begin{aligned}
\text { PPGN }= & h_{0}+h_{1} I R T+h_{2} J A K+h_{3} D_{2}+\mu_{8} \\
\text { PPGN = } & \text { Pengeluaran pokok pangan/The } \\
& \text { majorfood consumption. } \\
\text { JAK }= & \text { Jumlah anggota keluarga/The } \\
& \text { number offamilymembers. }
\end{aligned}
$$

\section{Pengeluaran beras (CBR)/ :}

$$
\begin{aligned}
\text { CBR }= & \mathrm{j}_{0}+\mathrm{j}_{1} I R T+\mathrm{j}_{2} \mathrm{JAK}+\mu_{10} \\
\text { CBR }= & \text { Pengeluaran beras/R ice } \\
& \text { consumption. }
\end{aligned}
$$

\section{Pengeluaran ikan $(\mathrm{Cl})$}

$\mathrm{Cl}=\mathrm{k}_{0}+\mathrm{k}_{1} \mathrm{IRT}+\mathrm{k}_{2} \mathrm{PDDI}+\mathrm{k}_{3} \mathrm{QMPMS}+\mu_{11}$ $\mathrm{Cl} \quad=\mathrm{Pengeluaran} \mathrm{ikan/Fish}$ consumption.

\section{Pengeluaran sayuran (CSy) :}

Csy $=\mathrm{I}_{0}+\mathrm{I}_{1} \mathrm{IRT}+\mathrm{I}_{2} \mathrm{Cl}+\mu_{12}$

CSy = Pengeluaran sayuran /vegetables consumption.

Analisis Ketahanan Pangan rumah tangga nelayan dilakukan dengan melihat nilai Indeks Angka Kecukupan Energi dan Indeks Angka Kecukupan Protein, mengacu pada hasil Widya Karya Nasional Pangan dan Gizi (WKNPG) tahun 2004. Selain itu juga mengukur Indeks Porsi Pengeluaran Pangan (IPORPGN) yang ditetapkan berdasarkan ketentuan bahwa rumahtangga dikatakan rawan pangan apabila $70 \%$ dari pendapatan total rumah tangga digunakan untuk konsumsi pangan.

\section{HASIL DAN PEMBAHASAN}

\section{PERILAKU EKONOMI RUMAHTANGGA NELAYAN}

\section{Perilaku Produksi melaut}

Perilaku berproduksi pada usaha penangkapan ikan pada umumnya dilakukan pada saat musim puncak dan musim sedang. Oleh karena itu model persamaan produksi melaut dapat dibedakan menjadi 2 yaitu model produksi musim puncak dan model produksi musim sedang. Hasil regresi produksi melaut disajikan pada Tabel 1.

Berdasarkan hasil analisis variance dengan pengujian kriteria F-value menunjukkan bahwa produksi melaut musim puncak dipengaruhi secara bersama-sama oleh variabel ukuran perahu dan jumlah cold box (UPJCB), jumlah bahan bakar motor (JBBMP), curahan kerja melaut musim puncak (THOKP), surplus rumah tangga nelayan (SRT) dan status sumberdaya penangkapan (D1).

Ukuran perahu dan jumlah cold box (UPJCB) yang lebih besar memudahkan nelayan dalam mengangkut hasil tangkapan pada musim puncak. Peningkatan penggunaan BBM akan meningkatkan hasil tangkapan ikan. Penggunaan BBM yang meningkat akan menyebabkan jangkauan daerah penangkapan ikan yang semakin luas dan meningkatkan produksi. Dalam hal curahan waktu kerja, nelayan cukup memanfaatkan curahan kerjanya pada musim puncak guna memperoleh hasil tangkapan yang banyak. Surplus rumah tangga nelayan kecil, berpengaruh positif nyata terhadap hasil produksi ikan pada musim puncak. Ini berarti adanya kelebihan pendapatan rumah tangga setelah dikeluarkan untuk konsumsi dimanfaatkan untuk kegiatan produksi melaut.

Status wilayah sumberdaya berpengaruh positif nyata. Ini berarti wilayah Kecamatan Prigi Kabupaten Trenggalek yang berada di wilayah laut selatan Jawa memiliki hasil produksi yang lebih tinggi dibandingkan dengan wilayah Kecamatan Lekok Kabupaten 
Tabel 1. Hasil Regresi Produksi Melaut.

Table 1. Regression of Fishing Production Behavior.

\begin{tabular}{|c|c|c|c|c|}
\hline Variabel/Variable & $\begin{array}{l}\text { Parameters } \\
\text { Estimation }\end{array}$ & $\begin{array}{l}\text { Standard } \\
\text { Error }\end{array}$ & $\begin{array}{c}\mathrm{t} \\
\text { Value }\end{array}$ & Prob > t \\
\hline Musim puncak/ Peak season & & & & \\
\hline $\begin{array}{l}\text { UPJCB/ Boat size and the } \\
\text { numbers of cool box }\end{array}$ & 2,1626 & 1,2764 & 1,694 & 0,095 \\
\hline $\begin{array}{l}\text { JBBMP/ The number of motor fuel } \\
\text { in peak season }\end{array}$ & 1,4386 & 0,2416 & 5,953 & 0,0001 \\
\hline $\begin{array}{l}\text { THOKP/Fishing allocation time in } \\
\text { peak season }\end{array}$ & 4,2796 & 3,1831 & 1,344 & 0,1835 \\
\hline SRT/Household surplus & 0,00005735 & 0,00001686 & 3,402 & 0,0011 \\
\hline $\begin{array}{l}\text { D1/ Catching resource status } \\
\mathrm{F} \text { Value }=33,196\end{array}$ & 1822,087473 & 389,706443 & 4,676 & 0,0001 \\
\hline $\begin{array}{l}\text { Prob }>F=0,0001 \\
\mathrm{R}^{2} \quad=0,7186 \\
\text { Musim sedang /Medium }\end{array}$ & & & & \\
\hline $\begin{array}{l}\text { season: } \\
\text { JBBMS/ The number of motor fuel }\end{array}$ & 1,1554 & 0,235108 & 4.915 & 0,0001 \\
\hline $\begin{array}{l}\text { in medium season } \\
\text { THOKS/ Fishing allocation time in }\end{array}$ & 12,333210 & 3,911084 & 3,153 & 0,0024 \\
\hline medium season & 0,000040737 & 0,000020303 & 2,006 & 0,0490 \\
\hline SRT/ Household surplus & 189,577604 & 151,967426 & 1,247 & 0,2167 \\
\hline 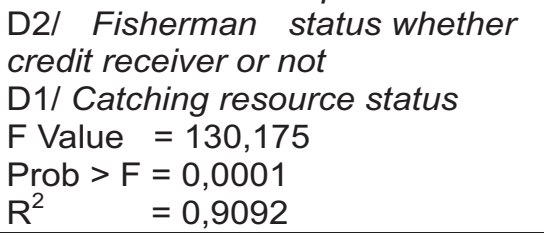 & 1037,635256 & 258,673869 & 4,011 & 0,0002 \\
\hline
\end{tabular}

Pasuruan yang berada di wilayah laut utara Jawa. Hal ini sesuai dengan temuan Muhammad (2002) pemanfaatan sumberdaya perikanan di wilayah laut utara telah melampaui tingkat MSY sehingga dalam kategori "over-exploited". Oleh karena itu pemanfaatan sumberdaya perikanan di wilayah laut selatan seperti wilayah Prigi lebih rendah dari MSY, sehingga masih dalam kategori "under-exploited".

Berdasarkan hasil analisis variance dengan pengujian kriteria F-value menunjukkan bahwa produksi melaut musim sedang dipengaruhi secara bersama-sama oleh variabel jumlah bahan bakar motor, curahan kerja melaut musim sedang, status nelayan penerima kredit atau bukan dan status sumberdaya wilayah penangkapan. Jumlah BBM yang digunakan dalam musim sedang berpengaruh positif nyata terhadap hasil produksi penangkapan ikan. Dalam hal curahan waktu kerja musim sedang, nelayan memanfaatkan curahan kerjanya untuk bekerja dengan giat, karena produksi ikan tidak sebanyak pada musim puncak. Surplus rumah tangga nelayan kecil berpengaruh positif nyata terhadap hasil produksi ikan pada musim sedang.

Status nelayan penerima kredit atau tidak, berpengaruh positif kurang nyata terhadap hasil produksi pada musim sedang. Hal ini berarti kredit yang diterima nelayan penerima kredit tidak secara langsung digunakan untuk meningkatkan produksi, namun lebih mengarah pada interaksi sosial dalam bentuk "patron-client". Berdasarkan analisis deskriptif, kredit nelayan banyak berupa uang tunai dimaksudkan sebagai 
ikatan kelangsungan dalam penjualan hasil tangkapan. Bakul ikan atau pengolah ikan memerlukan kontinuitas dalam memenuhi permintaan pabrik maupun untuk pengolahan ikan, sehingga memberikan kemudahan dalam peminjaman dalam bentuk uang tunai.

\section{Perilaku Curahan Kerja Melaut}

Usaha penangkapan ikan dilakukan pada saat musim puncak dan musim sedang. Oleh karena itu model persamaan curahan kerja melaut dapat dibedakan menjadi 2 yaitu model curahan kerja musim puncak dan musim sedang. Hasil regresi curahan kerja melaut disajikan pada Tabel 2.

Hasil analisis variance dengan pengujian kriteria $F$-value menunjukkan bahwa curahan kerja melaut musim puncak dipengaruhi secara bersama-sama oleh variabel pendapatan melaut pada musim puncak dan status sumberdaya penangkapan. Pendapatan melaut pada musim puncak berpengaruh positif nyata terhadap curahan kerja melaut musim puncak. Kenaikan pendapatan melaut akan menyebabkan individu menambah jam kerjanya. Dengan demikian sesuai dengan kurva penawaran tenaga kerja individu, pada musim puncak kondisi kurva naik.

Status wilayah sumberdaya berpengaruh negatif nyata, berarti wilayah Kecamatan Prigi Kabupaten Trenggalek memiliki curahan kerja pada musim puncak yang lebih rendah dibandingkan dengan wilayah Kecamatan Lekok Kabupaten Pasuruan. Pada musim puncak nelayan Prigi cenderung lebih rendah mencurahkan waktu kerjanya pada kegiatan penangkapan ikan di laut. Hal ini karena sumberdaya laut di Prigi masih dalam keadaan "under exploited" sehingga pada musim puncak nelayan Prigi relatif membutuhkan waktu yang lebih pendek untuk mencukupi hasil tangkapan ikan sesuai dengan kapasitas perahunya. Sementara perilaku waktu melaut nelayan di Lekok lebih panjang dibandingkan dengan nelayan Prigi. Sebagian besar dari nelayan Lekok menghabiskan waktu kerjanya pada kegiatan menangkap ikan di laut. Oleh

Tabel 2. Hasil Regresi Curahan Kerja Melaut.

Table 2. Regression of Fishing Time Allocated Behavior.

\begin{tabular}{|c|c|c|c|c|}
\hline Variabel/Variable & $\begin{array}{l}\text { Parameters } \\
\text { Estimation }\end{array}$ & $\begin{array}{l}\text { Standard } \\
\text { Error }\end{array}$ & $t$ value & Prob $>t$ \\
\hline \multicolumn{5}{|l|}{ Musim puncak/Peak season : } \\
\hline $\begin{array}{l}\text { KFMP/Fishing income in peak } \\
\text { season }\end{array}$ & 0,000007299 & 0,000001520 & 4,801 & 0,0001 \\
\hline $\begin{array}{l}\text { D1/ Catching resource status } \\
\text { F Value }=116,695\end{array}$ & $-140,550974$ & 10,649716 & $-13,198$ & 0,0001 \\
\hline $\begin{aligned} \text { Prob }>F & =0,0001 \\
R^{2} & =0,7744\end{aligned}$ & & & & \\
\hline \multicolumn{5}{|l|}{ Musim sedang/Medium season: } \\
\hline $\begin{array}{l}\text { ASET/Number of asset used by } \\
\text { fishing activities }\end{array}$ & 0,000000179 & 0,000001182 & 0,151 & 0,8802 \\
\hline $\begin{array}{l}\text { IRT/Household fisherles'total } \\
\text { income }\end{array}$ & 0,000002754 & 0,000000613 & 4,496 & 0,0001 \\
\hline $\begin{array}{l}\text { D1/ Catching resource status } \\
\text { F Value }=71,079\end{array}$ & 38,495577 & 9,067940 & 4,245 & 0,0001 \\
\hline $\begin{aligned} \text { Prob }>\mathrm{F} & =0,0001 \\
\mathrm{R}^{2} & =0,7609\end{aligned}$ & & & & \\
\hline
\end{tabular}


karena itu kurang ada perbedaan dalam curahan waktu kerja antara musim puncak maupun musim sedang pada nelayan Lekok.

Hasil pengujian kriteria F-value menunjukkan bahwa curahan kerja melaut musim sedang dipengaruhi secara bersamasama oleh variabel besarnya aset yang digunakan nelayan dalam kegiatan melaut, total pendapatan rumah tangga nelayan dan status sumberdaya penangkapan. Nilai aset kapal, alat tangkap dan mesin tidak berpengaruh nyata terhadap curahan kerja melaut pada musim sedang. Total pendapatan rumah tangga nelayan berpengaruh positif nyata terhadap curahan kerja melaut pada musim sedang. Total pendapatan rumah tangga terdiri dari pendapatan melaut, pendapatan off fishing dan pendapatan non fishing. Dengan meningkatnya total pendapatan rumah tangga maka nelayan skala kecil akan meningkatkan curahan waktu kerja di laut pada musim sedang. Pada musim sedang, nelayan skala kecil di wilayah Kecamatan Prigi Kabupaten Trenggalek memiliki curahan waktu kerja yang lebih tinggi dibandingkan dengan wilayah Kecamatan
Lekok Kabupaten Pasuruan. Hal ini disebabkan karena kondisi perairan di wilayah Kecamatan Lekok Kabupaten Pasuruan yang telah "over fishing". Sementara pada wilayah Kecamatan Prigi Kabupaten Trenggalek masih dalam kondisi "under fishing" sehingga pada saat musim sedang nelayan Prigi membutuhkan curahan waktu kerja yang lebih banyak dibandingkan dengan pada saat musim puncak, hingga melebihi curahan kerja nelayan Lekok.

\section{Biaya Operasi Melaut}

Model persamaan curahan kerja melaut dapat dibedakan menjadi 2 yaitu model curahan kerja musim puncak dan model curahan kerja musim sedang, seperti halnya pada pembahasan untuk model produksi melaut dan curahan kerja melaut. Hasil regresi total biaya melaut musim puncak disajikan pada Tabel 3.

Hasil analisis variance dengan pengujian kriteria $F$-value menunjukkan bahwa biaya operasi melaut baik musim puncak maupun musim sedang dipengaruhi secara bersamasama oleh variabel curahan kerja melaut pada

Tabel 3. Hasil Regresi Total Biaya Operasi Melaut.

Table 3. Regression Result of Fishing Operation Cost.

\begin{tabular}{|c|c|c|c|c|}
\hline Variabel/Variable & $\begin{array}{l}\text { Parameter } \\
\text { Estimation }\end{array}$ & $\begin{array}{l}\text { Standard } \\
\text { Error }\end{array}$ & t value & Prob $>t$ \\
\hline \multicolumn{5}{|l|}{ Musim puncak/Peak season: } \\
\hline $\begin{array}{l}\text { THOKPI Fishing allocation time in } \\
\text { peak season }\end{array}$ & 40230 & 2116,204271 & 19,011 & 0,0001 \\
\hline $\begin{array}{l}\text { ASET/ Number of asset used by } \\
\text { fishing activities }\end{array}$ & 0,211362 & 0,045362 & 4,659 & 0,0001 \\
\hline $\begin{aligned} \text { F Value } & =181,705 \\
\text { Prob }>F & =0,0001 \\
R^{2} & =0,8424\end{aligned}$ & & & & \\
\hline \multicolumn{5}{|l|}{ Musim sedang/Medium Season } \\
\hline $\begin{array}{l}\text { THOKS/ Fishing allocation time in } \\
\text { medium season }\end{array}$ & 55384 & 4771,866004 & 11,606 & 0,0001 \\
\hline $\begin{array}{l}\text { ASET/ Number of asset used by } \\
\text { fishing activities }\end{array}$ & 0,246186 & 0,073034 & 3,371 & 0,0012 \\
\hline \multicolumn{5}{|l|}{ F Value $=133,478$} \\
\hline \multicolumn{5}{|l|}{ Prob $>F=0,0001$} \\
\hline $\mathrm{R}^{2} \quad=0,7970$ & & & & \\
\hline
\end{tabular}


musim puncak atau sedang dan besarnya nilai asset yang digunakan nelayan kecil. Total curahan kerja melaut musim puncak berpengaruh positif nyata terhadap biaya operasi melaut musim puncak. Demikian juga dengan total curahan kerja melaut musim sedang dipengaruhi biaya operasi melaut musim sedang. Biaya operasi melaut terdiri dari biaya BBM, biaya perbekalan dan lainlain. Nilai aset yang dibutuhkan dalam kegiatan penangkapan ikan di laut berpengaruh positif nyata pada total biaya operasional melaut pada musim puncak maupun musim sedang. Nilai aset ini terdiri dari harga kapal, harga alat tangkap dan harga mesin penggerak perahu. Semakin besar nilai assetnya maka ukuran kapal dan mesin penggeraknya semakin lebih besar, sehingga untuk menggerakkan kapal tersebut diperlukan biaya bahan bakar yang lebih banyak. Demikian juga dengan biaya perbekalan dan biaya lainnya. Dengan demikian semakin besar nilai aset yang digunakan akan meningkatkan biaya operasi melaut.

\section{Pendapatan Non Perikanan Rumahtangga Nelayan}

Beberapa rumah tangga responden memiliki sumber pendapatan yang berasal dari kegiatan di luar bidang perikanan yang memiliki kontribusi yang cukup besar dalam sumbangan pendapatan rumah tangga nelayan kecil. Pada Tabel 4. disajikan hasil regresi penerimaan non perikanan.

Berdasarkan hasil analisis variance dengan pengujian kriteria F-value menunjukkan bahwa pendapatan non fishing dipengaruhi secara bersama-sama oleh variabel curahan kerja non fishing istri, curahan kerja non fishing suami, tingkat pendidikan istri dan total hari kerja melaut. Curahan kerja istri yang semakin tinggi akan meningkatkan pendapatan non perikanan dalam rumah tangga nelayan. Hal ini menunjukkan bahwa peran istri dalam kegiatan produksi pasar memberikan kontribusi yang sangat nyata terhadap pendapatan rumah tangga. Semakin tinggi curahan kerja suami pada kegiatan non fishing akan meningkatkan pendapatan non perikanan rumah tangga nelayan. Pendidikan istri berpengaruh positif kurang nyata terhadap pendapatan non fishing. Hal ini disebabkan karena jenis pekerjaan istri pada umumnya hanya membutuhkan kemauan untuk bekerja dan ketrampilan dalam usahanya. Semakin tinggi total hari orang kerja fishing dalam rumah tangga nelayan menyebabkan pendapatan non fishing rumah tangga nelayan meningkat. Ini berarti bahwa rumah tangga

Tabel 4. Hasil Regresi Pendapatan Non Perikanan.

Table 4. Regression of Non-Fishing Income.

\begin{tabular}{lrrrr}
\hline \multicolumn{1}{c}{ Variabel/Variable } & $\begin{array}{c}\text { Parameter } \\
\text { Estimation }\end{array}$ & $\begin{array}{c}\text { Standard } \\
\text { Error }\end{array}$ & $t$ value & Prob $>\mathrm{t}$ \\
\hline $\begin{array}{l}\text { KNFI/ Wives' productivity time } \\
\text { allocation }\end{array}$ & 15,422 & 1905,748325 & 8,092 & 0,0001 \\
KNFS/ Husbands' non -fishing & $7043, .296329$ & 4495,369559 & 1,567 & 0,1219 \\
time allocation & & & \\
PDDI/Wives educational level & 21,964 & 75,567 & 0,291 & 0,7722 \\
THOK/ Total fishing time & 8536,856170 & 4095,822472 & 2,084 & 0,0410 \\
allocated days & & & \\
F Value $=31,750$ & & & & \\
Prob $>\mathrm{F}=0,0001$ & & & & \\
$\mathrm{R}^{2}=0,6580$ & & & & \\
\hline
\end{tabular}


nelayan sangat giat dalam kegiatan berproduksi baik produksi fishing maupun non fishing. Pendapatan rumah tangga yang tinggi merupakan cara rumah tangga nelayan untuk mencapai ketahanan pangan.

\section{Perilaku Pengeluaran Pangan}

Pola pengeluaran pokok pangan merupakan salah satu indikator tingkat kesejahteraan rumah tangga. Semakin tinggi pendapatan maka persentase yang digunakan untuk pengeluaran pokok pangan makin berkurang dan bergeser untuk pengeluaran non pangan. Proporsi pengeluaran rumah tangga terhadap bahan pangan merupakan salah satu indikator ketahanan pangan di tingkat rumah tangga. Hasil regresi disajikan pada Tabel 5 .

Berdasarkan pengujian kriteria $F$ value, pengeluaran pokok pangan rumahtangga nelayan dipengaruhi secara bersama-sama oleh total pendapatan rumah tangga, jumlah anggota keluarga, dan status nelayan penerima kredit. Semakin tinggi pendapatan rumahtangga maka semakin meningkat pula pengeluaran pokok pangan dalam rumahtangga nelayan. Ini berarti apabila pendapatan rumah tangga meningkat, maka rumah tangga ingin meningkatkan kualitas pangan. Dengan demikian anggaran untuk pengeluaran pokok pangan lebih meningkat.
Semakin banyak anggota keluarga, maka akan semakin meningkatkan pengeluaran pokok pangan dalam rumah tangga nelayan. Status nelayan penerima kredit mempengaruhi pula pengeluaran pokok rumah tangga nelayan. Kredit yang diberikan nelayan dari para bakul ikan sebagai ikatan dalam penjualan hasil tangkapan lebih digunakan untuk pengeluaran pokok pangan, dan hanya sebagian kecil digunakan untuk kegiatan produksi. Hal ini sesuai dengan Tabel 1 menunjukkan bahwa status nelayan penerima kredit kurang berpengaruh nyata terhadap produksi melaut pada musim sedang.

Kebutuhan konsumsi pangan rumah tangga yang mendasar guna terpenuhi pola hidup sehat harus memenuhi 4 sehat 5 sempurna yaitu karbohidrat, protein, sayuran, buah-buahan dan susu. Perilaku konsumsi pangan rumah tangga nelayan berikut dilihat berdasarkan pemenuhan kebutuhan beras sebagai sumber karbohidrat, ikan sebagai pemenuhan protein serta sayuran. Padipadian seperti beras, jagung, atau gandum merupakan bagian terbesar (60-80 persen) dari susunan pangan penduduk yang tinggal di negara-negara Asia Tenggara (Herper et al, 1986). Bahan makanan tersebut adalah sumber karbohidrat yang baik serta sebagai sumber tenaga. Oleh karena itu konsumsi

Tabel 5. Hasil Regresi Pengeluaran Pokok Pangan Rumahtangga Nelayan.

Table 5. Regression of the Major Food Expenditure of Fisher's Household.

\begin{tabular}{|c|c|c|c|c|}
\hline Variabel/Variable & $\begin{array}{c}\text { Parameter } \\
\text { Estimasi }\end{array}$ & $\begin{array}{l}\text { Standard } \\
\text { Error }\end{array}$ & $t$ value & Prob $>t$ \\
\hline $\begin{array}{l}\text { IRT/ Household fisheries' total } \\
\text { income }\end{array}$ & 0,093435 & 0,012170 & 7,677 & 0,0001 \\
\hline $\begin{array}{l}\text { JAKI The number of family } \\
\text { members }\end{array}$ & 970131 & 84399 & 11,495 & 0,0001 \\
\hline $\begin{array}{l}\text { D2/ Fisherman status whether } \\
\text { credit receiver or not }\end{array}$ & 501738 & 200959 & 2,497 & 0,0150 \\
\hline F Value $=71,079$ & & & & \\
\hline $\begin{aligned} \text { Prob }>F & =0,0001 \\
R^{2} & =0,7609\end{aligned}$ & & & & \\
\hline
\end{tabular}


beras merupakan salah satu indikator ketahanan pangan dalam model ekonomi rumah tangga nelayan skala kecil. Ikan merupakan hasil tangkapan nelayan, selain dijual untuk dipertukarkan dengan beras dan kebutuhan lain, juga dikonsumsi sendiri guna mencukupi kebutuhan protein. Hasil regresi konsumsi beras, ikan dan sayuran disajikan pada Tabel 6.

Berdasarkan hasil analisis variance dengan pengujian kriteria $F$-value menunjukkan bahwa konsumsi beras secara bersama-sama dipengaruhi oleh variabel total pendapatan rumah tangga nelayan dan jumlah anggota keluarga. Secara parsial kenaikan total pendapatan rumahtangga nelayan secara langsung tidak meningkatkan konsumsi beras. Ini berarti konsumsi beras dalam rumah tangga responden telah tercukupi, dengan nilai rata-rata 260 gram/orang/hari. Semakin banyak jumlah anggota keluarga maka semakin bertambah kebutuhan beras untuk memenuhi konsumsi beras dalam rumah tangga nelayan.

Konsumsi ikan dalam rumah tangga nelayan kecil secara bersama-sama dipengaruhi oleh total pendapatan dalam rumah tangga, tingkat pendidikan ibu dan total produksi melaut berdasarkan uji kriteria F-value. Secara parsial kenaikan total pendapatan rumah tangga nelayan secara langsung kurang meningkatkan konsumsi ikan, karena rumah tangga nelayan mencukupi kebutuhan konsumsi ikan berasal dari hasil tangkapan, bukan dari membeli. Tingkat pendidikan istri berpengaruh positif

Tabel 6. Hasil Regresi Konsumsi Beras, Ikan dan Sayuran

Table 6. Regression Result of Rice, Fish, and Vegetables Consumptions

\begin{tabular}{|c|c|c|c|c|}
\hline Variabel/Variable & $\begin{array}{l}\text { Parameter } \\
\text { Estimation }\end{array}$ & $\begin{array}{l}\text { Standard } \\
\text { Error }\end{array}$ & $t$ value & Prob > t \\
\hline \multicolumn{5}{|l|}{ Konsumsi beras/ Rice } \\
\hline $\begin{array}{l}\text { consumption: } \\
\text { IRT/ Household fisheries' total } \\
\text { income }\end{array}$ & 0,000001148 & 0,000001528 & 0,752 & 0,4548 \\
\hline $\begin{array}{l}\text { JAKI The number of family } \\
\text { members }\end{array}$ & 54,665311 & 6,491306 & 8,421 & 0,0001 \\
\hline $\begin{array}{l}\mathrm{F} \text { Value }=288,654 \\
\text { Prob }>\mathrm{F}=0,0001 \\
\mathrm{R}^{2}=0,8932 \\
\text { Konsumsi ikan/ Fish } \\
\text { consumption: }\end{array}$ & & & & \\
\hline $\begin{array}{l}\text { IRT/ Household fisheries' total } \\
\text { income }\end{array}$ & 0,000000700 & 0,000000814 & 0,859 & 0,3934 \\
\hline PDDI/ Wives educational level & 2,747470 & 1,535813 & 1,789 & 0,0781 \\
\hline 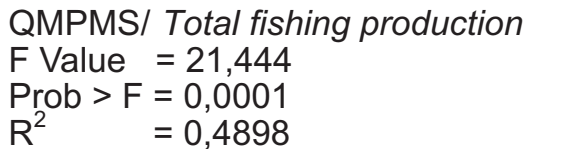 & 0,008945 & 0,002698 & 3,316 & 0,0015 \\
\hline $\begin{array}{l}\text { Konsumsi sayurl Vegetable } \\
\text { consumption: }\end{array}$ & & & & \\
\hline $\begin{array}{l}\text { IRT/ Household fisheries' total } \\
\text { income }\end{array}$ & 0,000002837 & 0,000001814 & 1,564 & 0,1224 \\
\hline $\begin{array}{l}\text { Cl/ Fish consumption } \\
\mathrm{F} \text { Value }=37,494 \\
\text { Prob }>\mathrm{F}=0,0001 \\
\mathrm{R}^{2} \quad=0,5244\end{array}$ & 1,768705 & 0,470005 & 3,763 & 0,0004 \\
\hline
\end{tabular}


nyata terhadap konsumsi ikan dalam rumah tangga nelayan. Semakin tinggi tingkat pendidikan ibu, maka semakin meningkat konsumsi ikan dalam rumah tangga nelayan. Dengan pendidikan yang tinggi, maka akan semakin luas ilmu pengetahuannya, serta akan mudah bagi seorang ibu untuk memahami arti pentingnya gizi dan kebutuhan protein. Semakin banyak produksi hasil tangkapan, maka semakin meningkat pula bagian dari produksi tersebut untuk dikonsumsi sendiri. Tidak semua produksi hasil tangkapan ikan dijual, namun beberapa bagian dari hasil tangkapan dikonsumsi sendiri sebagai "lawuhan" (lauk pauk).

Konsumsi sayur dipengaruhi secara bersama-sama oleh variabel total pendapatan dalam rumahtangga nelayan dan konsumsi ikan melalui pengujian kriteria F-Value. Kenaikan total pendapatan rumah tangga nelayan secara langsung kurang meningkatkan konsumsi sayur, karena sebagian besar responden dari wilayah Prigi mencukupi kebutuhan konsumsi sayur berasal dari hasil tanaman sendiri, bukan dari membeli. Semakin banyak konsumsi ikan dalam rumah tangga nelayan, maka semakin meningkat kebutuhan rumahtangga terhadap konsumsi sayur. Ini berarti antara ikan dan sayur merupakan kebutuhan konsumsi yang saling melengkapi (komplementer).

\section{Profil Ketahanan Pangan Rumah Tangga Nelayan}

Di daerah Tasikmadu nilai rata-rata AKE sebesar 1.760,83 kkal/orang/hari, dan di daerah Jatirejo sebesar 1.628,92 kkal/orang/hari. Data AKE pada masingmasing daerah penelitian disajikan pada Tabel 7 dan 8.

Tabel 7. menunjukkan rata-rata nilai konsumsi energi rumah tangga nelayan baik di daerah Tasikmadu Trenggalek maupun di daerah Jatirejo Pasuruan berada di bawah standar angka kecukupan energi yang harus dipenuhi tiap hari berdasarkan ketentuan hasil Widya Karya Nasional Pangan dan Gizi (WKNPG) sebesar $2000 \mathrm{Kkal} /$ orang/hari. Namun secara umum ketahanan rumahtangga nelayan responden baik di daerah Tasikmadu maupun di daerah Jatirejo termasuk ke dalam rumah tangga tahan pangan (food secure) dan bukan rumah tangga yang bermasalah dalam hal kecukupan konsumsi pangan sehari-hari

\section{Tabel 7. Nilai Angka Kecukupan Energi/Orang/Hari di Daerah Penelitian.}

Table 7. Value of AKE/Person/Day in the Research Site.

\begin{tabular}{|c|c|c|c|}
\hline No & $\begin{array}{l}\text { Kelompok Pangan/ } \\
\text { Food Group }\end{array}$ & Tasikmadu (kkal) & Jatirejo (kkal) \\
\hline 1 & Beras/ Rice & 956,67 & $1.086,00$ \\
\hline 2 & $\begin{array}{l}\text { Umbi-umbian/jagung/ } \\
\text { Corn }\end{array}$ & 123,32 & 56,18 \\
\hline 3 & Tahu/Tofu & 6,63 & 3,60 \\
\hline 4 & Tempe/tempeh & 14,53 & 7,89 \\
\hline 5 & Ikan/ Fish & 150,32 & 93,33 \\
\hline 6 & Telur / Egg & 21,52 & 10,95 \\
\hline 7 & Daging/Meat & 0,00 & 0,00 \\
\hline 8 & Sayuran/Vegetables & 194,01 & 11,85 \\
\hline 9 & Minyak goreng/Coconut oil & 216,41 & 243,89 \\
\hline 10 & Gula /Sugar & 107,71 & 115,21 \\
\hline \multirow[t]{2}{*}{11} & Lainnya (kelapa)/ Coconut & 22,08 & 0,00 \\
\hline & Jumlah/Total & $1.760,83$ & $1.628,92$ \\
\hline
\end{tabular}


(rumah tangga tidak defisit kalori dan/atau protein) karena tingkat konsumsi lebih dari 70\% dari Angka Kecukupan Energi yang dianjurkan, yaitu sebesar 88,04\% untuk daerah Tasikmadu dan 81,45 \% untuk daerah Jatirejo. Berdasarkan perhitungan, maka Indeks AKE di daerah Tasikmadu sebesar 0,90 dan di daerah Jatirejo lebih rendah dari Tasikmadu yaitu 0,71 .

Berdasarkan hasil tabulasi, rata-rata nilai Angka Kecukupan Protein di daerah Tasikmadu sebesar 63,82 gram/orang/hari sedangkan pada daerah Jatirejo sebesar 41,88 gram/orang/hari. Nilai Angka Kecukupan Protein di daerah penelitian disajikan pada Tabel 8.

Dari Tabel 8. dapat dilihat bahwa rata-rata konsumsi protein rumahtangga nelayan di daerah Tasikmadu Trenggalek lebih besar dibandingkan dengan daerah Jatirejo Pasuruan. Bahkan di daerah Tasikmadu berada di atas standar angka kecukupan protein yang harus dipenuhi berdasarkan ketentuan hasil Widya Karya Nasional Pangan dan Gizi (WKNPG) sebesar 52 gram/orang/hari.

Berdasarkan perhitungan nilai Indeks AKP di daerah Tasikmadu sebesar 1,24. Peran ikan laut sebagai sumber protein sebesar $42,05 \%$ dari total rata-rata konsumsi protein oleh rumah tangga nelayan. Dalam satu tahun rata-rata anggota keluarga mengkonsumsi ikan sebesar 49,44 kg/kapita/tahun. Hal ini menunjukkan bahwa tingkat konsumsi ikan rumahtangga nelayan skala kecil di Desa Tasikmadu jauh lebih tinggi dari tingkat konsumsi ikan yang dicanangkan oleh Departemen Kelautan dan Perikanan (DKP) pada tahun 2007 sebesar $28 \mathrm{~kg} / \mathrm{kapita} / \mathrm{tahun}$.

Rata-rata konsumsi protein di daerah Jatirejo Pasuruan sebesar 41,88 gram/orang/hari. Hal ini menunjukkan bahwa konsumsi protein di daerah Jatirejo berada di bawah standar angka kecukupan protein yang harus dipenuhi berdasarkan ketentuan hasil Widya Karya Nasional Pangan dan Gizi (WKNPG) sebesar 52 gram/orang/hari. Namun daerah Jatirejo bukan rumah tangga yang bermasalah dalam hal kecukupan konsumsi pangan sehari-hari (rumah tangga tidak defisit kalori dan/atau protein) karena tingkat konsumsi protein lebih dari $70 \%$ dari Angka Kecukupan protein yang dianjurkan sebesar 36,4 gram/orang/hari.

Berdasarkan perhitungan nilai Indeks AKP di wilayah Jatirejo sebesar 0,74. Sumber

Tabel 8. Nilai Angka Kecukupan Protein/Orang/Hari di Daerah Penelitian. Table 8. Value of AKP/Person/Day on in Research Site.

\begin{tabular}{llrr}
\hline No & \multicolumn{1}{c}{$\begin{array}{c}\text { Kelompok Pangan/ } \\
\text { Food Group }\end{array}$} & $\begin{array}{c}\text { Tasikmadu } \\
\text { (gram) }\end{array}$ & $\begin{array}{r}\text { Jatirejo } \\
\text { (gram) }\end{array}$ \\
\hline 1 & Beras/ Rice & 18,07 & 20,51 \\
2 & Umbi-umbian/jagung/ & 1,01 & 1,35 \\
& Corn & & \\
3 & Tahu/Tofu & 0,76 & 0,41 \\
4 & Tempe/tempeh & 1,78 & 0,97 \\
5 & Ikan/ Fish & 26,84 & 16,67 \\
6 & Telur/ Egg & 1,70 & 0,87 \\
7 & Daging/Meat & 0,00 & 0,00 \\
8 & Sayuran/Vegetables & 13,19 & 0,81 \\
9 & Minyak goring/coconut oil & 0,25 & 0,28 \\
10 & Gula /Sugar & 0,00 & 0,00 \\
11 & Lainnya (kelapa) )/ Coconut & 0,21 & 0,00 \\
& Jumlah/Total & $\mathbf{6 3 , 8 2}$ & $\mathbf{4 1 , 8 8}$ \\
\hline
\end{tabular}


protein terbesar diperoleh dari konsumsi ikan. Dalam satu tahun rata-rata anggota rumah tangga mengkonsumsi ikan sebesar 29,33 $\mathrm{kg} / \mathrm{Kapita} /$ tahun. Angka ini telah memenuhi target konsumsi makan ikan yang dicanangkan Departemen Kelautan dan Perikanan pada tahun 2007 sebesar 28 $\mathrm{kg} /$ Kapita/tahun.

Indeks Ketahanan Pangan dalam penelitian ini diukur berdasarkan rata-rata jumlah dari nilai Indeks AKE, Indeks AKP dan Indeks Pengeluaran Pangan. Apabila nilai Indeks Ketahanan Pangan rumahtangga kurang dari 1 maka rumah tangga tersebut kurang tahan pangan. Berdasarkan pada ukuran tersebut, maka diperoleh nilai Indeks Ketahanan Pangan di wilayah Tasikmadu sebesar 1,63 dan di wilayah Jatirejo sebesar 1,02. Ini berarti kedua daerah penelitian termasuk daerah yang tahan pangan.

Daerah Tasikmadu Trenggalek memiliki Indeks Ketahanan Pangan yang lebih bagus dibandingkan daerah Jatirejo Pasuruan. Hal ini terkait dengan perilaku ekonomi rumah tangga nelayan serta status sumberdaya perikanan. Menurut Muhammad (2002) status sumberdaya perikanan wilayah laut utara (wilayah Jatirejo Pasuruan) telah "overexploited", sedangkan sumberdaya di wilayah laut selatan (Tasikmadu Trenggalek) masih dalam kategori "under-exploited". Perilaku ekonomi rumahtangga dapat antara lain; di wilayah Tasikmadu Trenggalek seluruh nelayan responden tidak hanya mencurahkan waktu kerja di laut saja, namun juga mengerjakan ladang perhutani saat tidak musim ikan. Nelayan di daerah Jatirejo Pasuruan umumnya menghabiskan waktu kerjanya dilaut. Sumbangan pendapatan istri nelayan terhadap pendapatan rumah tangga nelayan juga menentukan Indeks Ketahanan Pangan. Didaerah Tasikmadu Trenggalek 85\% istri nelayan responden memberikan kontribusi terhadap pendapatan rumahtangga, sedangkan di Jatirejo Pasuruan hanya $47,5 \%$ istri nelayan responden bekerja pada pasar tenaga kerja. Dengan dimikian, pendapatan rumah tangga di wilayah Tasikmadu Trenggalek lebih tinggi dibandingkan dengan wilayah Jatirejo Pasuruan.

\section{KESIMPULAN DAN IMPLIKASI KEBIJAKAN}

\section{Kesimpulan}

1. Rumah tangga nelayan skala kecil melakukan kegiatan produksi penangkapan pada musim puncak dan sedang, produksi non penangkapan seperti buruh perikanan, pengolahan ikan dan non perikanan seperti penggarap lahan perhutani, berdagang, dan lain-lain. Pendapatan rumah tangga berasal dari pendapatan melaut dan non perikanan. Kredit nelayan dari bakul ikan lebih digunakan untuk konsumsi pangan, sebagai salah satu strategi coping dalam rumah tangga nelayan. Konsumsi pangan dengan nilai porsi pengeluaran pangan terhadap pendapatan total sebesar $35,4 \%$ atau Indeks Porsi Pengeluaran Pangan 2,36 . Konsumsi non pangan untuk pengeluaran listrik, sandang, kesehatan, pendidikan dan kegiatan sosial.

2. Nilai AKE sebesar 1.637,00 Kkal/orang/hari atau Indeks AKE 0,82 menunjukkan bahwa rumah tangga nelayan skala kecil termasuk ke dalam rumahtangga tahan pangan (food secure) dan bukan rumahtangga yang bermasalah dalam hal kecukupan konsumsi pangan sehari-hari (rumah tangga tidak defisit kalori). Sedangkan nilai AKP sebesar 53,48 gram/orang/hari atau Indeks AKP 1,03 yang menunjukkan bahwa rumahtangga nelayan skala kecil telah tercukupi kebutuhan protein sehari-hari. Berdasarkan nilai Indeks Porsi Pengeluaran Pangan, Indeks AKE dan Indeks AKP didapatkan nilai Indeks Ketahanan Pangan sebesar 1,40 menunjukkan bahwa rumahtangga nelayan skala kecil tahan pangan. 


\section{Implikasi Kebijakan}

1. Kredit nelayan dari bakul ikan lebih digunakan untuk konsumsi pangan. Oleh karena itu pemberian kredit hendaknya dalam bentuk peralatan produksi melaut yang diperlukan nelayan agar penggunaan kredit tepat sasaran.

2. Salah satu cara untuk mengurangi penggunaan kredit produksi untuk kegiatan konsumsi dapat dilakukan melalui peningkatan peran wanita dalam kegiatan produktif menuju kemandirian ekonomi rumah tangga. Oleh karena itu diperlukan kajian yang lebih mendalam tentang peluang berusaha wanita nelayan dilokasi penelitian untuk pengembangan usaha produktif wanita nelayan menuju industrialisasi pedesaan berbasis sumberdaya lokal.

\section{DAFTAR PUSTAKA}

Aryani, F. 1994. Analisis Curahah Kerja dan Konstribusi Penerimaan Keluarga Nelayan Dalam Kegiatan Ekonomi di desa Pantai. PPS-IPB. Bogor, Thesis.

Direktorat Jenderal Perikanan,1993. Evaluasi pembangunan Sub sektor Perikanan Dalam pembangunan Jangka Panjang Tahap I (PJPTI), Jakarta.

FAO, 2005. Increasing The Contribution of Small-Scale Fisheries to Poverty Alleviation and Food Security. Rome.

Herper, Laura J, Brody J. D. dan Judy A. D. 1986. Pangan, Gizi, dan Pertanian. Penerjemah: Suharjo. UI-Pres. Jakarta.

Muhammad, S. E. Susilo, A. Qoid dan M. Primyastanto, 1991. Analisis Pengembangan Usaha Perikanan Skala kecil di selat Madura. Fakultas Perikanan Universitas Brawijaya Malang.
Muhammad, S. 2002. Kajian Ekonomi Rumah Tangga Nelayan di Jawa Timur: Analisis Simulasi Kebijakan, Pemanfaatan Sumberdaya Perikanan. PPS IPB. Bogor. Disertasi S-3.

Nazir, M. 2003. Metodologi Penelitian. Cetakan Kelima. Ghalia Indonesia. Jakarta.

Purwanti, P. 1994. Curahan Waktu dan Produktivitas Kerja Nelayan di Kabupaten Pasuruan. FPS UGM, Yogyakarta. Thesis S-2

Purwono. G.S, 1991, Alokasi Waktu dan Produktivitas Nelayan di Kecamatan Puger Kabupaten Jember, FPS UGM, Yogyakarta. Thesis S-2

Qoid, A. S.Muhammad, dan M. Musa. 2004. Studi Ekonomi Rumah Tangga Nelayan Pada Perikanan Padat Tangkap di Selat Bali-Muncar. Fakultas Perikanan Universitas Brawijaya Malang.

Reniati, 1998, Faktor-Faktor yang mempengaruhi dan keterkaitan Keputusan Kerja Produksi dan pengeluaran Rumahtangga Nelayan, PPS. IPB. Thesis S.2.

Sutoyo. 2005. Kajian Ekonomi Rumah Tangga Nelayan Kecil Pada Program Pemberdayaan Pengelolaan Sumberdaya Berbasis Komunitas (PSBK) (Kasus di Muncar Banyuwangi). PPS Unibraw. Malang. Thesis S-2.

Tumulyadi, A. 2005. Analisa Ekonomi Rumah Tangga Nelayan Rumpon (Kasus Penangkapan Ikan Cakalang dan Tuna dengan alat Bantu Rumpon di PPI Pondokdadap - Kabupaten Malang. PPS Unibraw. Malang. Thesis S-2.

Walpole, RE. 1995. Pengantar Statistika Edisi ke-3. PT. Gramedia Pustaka Utama. Jakarta. 
